\title{
The Role of the Sociocultural Environment of Inclusion in the Modern Educational Institution
}

\author{
Nadiia Chernukha ${ }^{1}$, Mariana Petrova ${ }^{2}$, Maryna Vasylieva-Khalatnykova $^{1}$, Zoriana Krupnyk $^{3}$ \& Yuliia Krasilova ${ }^{1}$ \\ ${ }^{1}$ Taras Shevchenko National University of Kyiv, Kiev, Ukraine \\ ${ }^{2}$ St. Cyril and St. Methodius University of Veliko Tarnovo, Veliko Tarnovo, Bulgaria \\ ${ }^{3}$ Tepnopil National Economic University, Ternopil, Ukraine \\ Correspondence: Mariana Petrova, St. Cyril and St. Methodius University of Veliko Tarnovo, Bulgaria.
}

Received: November 17, 2020

Accepted: January 21, 2021

Online Published: January 22, 2021

doi:10.5430/ijhe.v10n3p211

URL: https://doi.org/10.5430/ijhe.v10n3p211

\begin{abstract}
The article presents a consideration of the peculiarities of the organization of the socio-cultural environment of inclusion in a modern educational institution. The new conceptual foundations of social order, as stated in the UN Declaration on Social Development, are the ability of modern society to develop on the basis of tolerance, tolerance, condemnation of discrimination, respect for human diversity, equality of opportunity, solidarity and security. It is noted that the basis of such integration is the concept of a holistic approach, which opens the way to the realization of rights and opportunities for everyone and, above all, provides equal access to quality education. It is emphasized that the principle of accessibility, which is leading in the holistic approach of modern social policy and is formulated on the basis of respect for human rights. The aim of the article is to reveal the content of the socio-cultural environment of inclusion in a modern educational institution. The socio-cultural environment of inclusion in a modern educational institution is analyzed. Analysis of the definitions of socio-cultural environment allowed to form our own definition of the phenomenon for people with disabilities: socio-cultural environment - is the environment of people in the educational institution, including social groups, information flows, the influence of various public organizations, cultural and educational activities; jointly influence the change and formation of internal attitudes and external characteristics of the object and its socialization. The peculiarities of the socio-cultural environment of inclusion in a modern educational institution are determined. A model of the socio-cultural environment of an educational institution for a person with a disability has been developed and represented, which includes external and internal factors influencing its components, contribution flows and products.
\end{abstract}

Keywords: inclusion, inclusion model, person with disabilities, socio-cultural environment

\section{Introduction}

Everyone, regardless of health status, physical or intellectual disability, has the right to receive education whose quality does not differ from the quality of education of healthy people.

At the current stage of development of education in our world, one of the possible options for including a child with psychophysical disorders in the general education space is inclusion, which means that a child with disabilities has the right to attend a secondary school with the necessary adapted educational environment benefit from their joint learning with healthy peers. The spread of inclusion is closely linked to the processes of democratization of public consciousness, international recognition of the right of everyone to a full life and education.

To date, there is some consensus on the importance of integrating people with disabilities into society. This stage is associated with the transformation of society and the state of its attitude to people with disabilities, recognizing not only the equality of its rights, but also society's awareness of its obligation to provide such people with all other opportunities in various spheres of life, including education.

Highlighting the social aspect of compensatory ability, L. Vygotsky noted that "... physical defect causes a social dislocation, completely similar to bodily dislocation, when the damaged organ - arm or leg - comes out of the joint, when rudely ruptured habitual ligaments and organ function is accompanied pain and inflammation. ..If psychologically a physical defect means a social dislocation, then pedagogically to bring up such a child means to direct it to life, as a dislocated or diseased organ is exercised "(Vygotsky L., 2003). 
Obviously, today the emphasis shifts from human adaptation to the environment towards the adaptation of the environment to meet their own human needs.( Nikolova, 2015; Nikolova, 2016; Badjanova et al, 2020; Badjanova et al, 2018; Jarmusevica et al, 2019a; Jarmusevica et al, 2019b).

Recognition of the rights of such a person, his interests, needs, assistance in the process of socialization and choice of professional activity is very important at the present stage of educational development (Dyachenko et al, 2018; Duginets \& Petrova, 2020; Mushkudiani et al, 2020; Petrova, Buzko \& Dyachenko, 2018). Therefore, the socio-cultural environment of inclusion in a modern educational institution is of great importance, which provides for the coexistence of children with mental and physical disabilities with their healthy peers.

It should be noted that at the present stage society (in the broadest sense of the word) has "come" to the recognition and affirmation of the right of a person with disabilities to participate fully in public life and is in the process of realizing the need for full realization of this right.

Diagnostic study of impact is important in the theory of inclusive education environment for the development of a child with psychophysical disorders. After all, each participant inclusion requires the creation of conditions for its development and education. On the one hand, healthy children must learn to accept "special" peers, and on the other - for children with disabilities special opportunities for their development and education should be created by health opportunities inclusive environment.

Summarizing the above, we emphasize that the relevance of the study of the role of socio-cultural environment of inclusion in modern education will help to overcome certain problems, such as: social adaptation of people with disabilities, maintaining and continuing their social activity, personal development, giving them opportunities to use useful and enjoyable time, meeting various cultural and educational needs, needs for communication and recognition, as well as awakening new interests, facilitating the establishment of friendly relations, activation of personal activity of wards, formation, support and increase their vitality.

The purpose of the article is to reveal the content of the socio-cultural environment of inclusion in a modern educational institution

\section{Objectives of the study:}

1) to analyze the socio-cultural environment of inclusion in a modern educational institution;

2) to determine the features of the socio-cultural environment of inclusion in a modern educational institution;

3) to represent the model of the socio-cultural environment of the educational institution for a person with a disability.

\section{Methods}

General scientific methods are used to solve problems:

1) method of analysis and synthesis (in order to reveal the conceptual and categorical apparatus of research and scientific substantiation);

2) scientific abstraction, induction and deduction (summarizing domestic and foreign experience in the study of this issue);

3) abstract-logical (for theoretical generalization of research results and formulation of conclusions);

4) special methods: mathematical and statistical processing of research results (for survey analysis);

5) cross-tabulating and filtering results (for survey analysis);

5) comparative data (for survey analysis);

6) data analysis (for survey analysis);

7) systematization and differentiation (for survey analysis);

8) grouping, mean, standard deviation, regression, sample size determination, hypothesis testing (for survey analysis);

9) customized excel spreadsheets, graphic expression of data (for survey analysis).

The using of the different methods represents the resultant data that is collected from a sample of respondents that took a survey. This data is comprehensive information gathered from a target audience about a particular topic of interest to conduct research on the basis of this collected data. All methods allowed obtaining objective information 
about the socio-pedagogical conditions of professional education of future social specialists to a successful professional career. The results of the study are presented using diagrams, tables and figures.

\section{Analysis of the Research and Publications}

Inclusion (from Inclusion - inclusion) - the process of increasing the degree of participation of all citizens in social life. It is a policy and process that enables all children to participate in all programs.

Inclusive education is a system of educational services based on the principle of ensuring the basic right of children to education and the right to receive it at the place of residence, which provides for the education of a child with special educational needs in a secondary school.

One of the main tasks of inclusion is to respond to a wide range of educational needs in the school environment and beyond.

Inclusive education is based on an ideology that excludes any discrimination against children, which ensures equal treatment for all people, but creates special conditions for children with special needs.

Inclusive education values the diversity and unique role of each person in the educational process. In a real socio-cultural environment of inclusion of a modern educational institution, everyone feels safe and has a sense of belonging to the team. All subjects of the educational process are involved in defining learning goals, as well as in making decisions that affect them. And employees of modern educational institutions, in turn, have the necessary qualifications, support, flexibility and resources to educate, encourage and respond to the needs of people with disabilities. (Diachok et al, 2020; Zagorodnya, Chernukha \& Petrova, 2020; Ivanchuk et al, 2020)

Inclusive education is guided by the emotional aspects of the impact on a person with a disability, and the created socio-cultural environment of inclusion is influenced by the ease of communication or the already created level of comfort. Ensuring quality inclusive education is possible only if a "safe space" is created. Here the emphasis is on dialogue, not discussion. This allows for complex, emotionally charged questions, listening deeply to another's point of view, without judging and alienating one's own views (Christine Ann Walsh et al, 2012; Myra Baynton et al 2012).

The inclusion environment of a modern educational institution provides the best quality of education for all children and is a fundamental factor in eliminating discriminatory approaches. Modern educational institutions create an environment of inclusion in which there are constant active human interactions with disabilities and the world outside their families, which allows to develop social relations and skills of forming relationships and joint actions. Respect and understanding increase when people with different abilities and different backgrounds play, communicate and learn together.

The educational environment in modern educational institutions excludes and segregates certain groups of children, increases discrimination against traditionally marginalized groups. When the educational environment becomes socio-cultural and largely inclusive, the everyday phenomena of citizen participation in public affairs, employment and public life become the same.

One of the goals of inclusion as a process in education is to provide access to education taking into account the capabilities of a person with disabilities (Baida L., 2003), (Vasilieva-Khalatnikova M., 2019), (Boy M., 2015), (Mironova S., 2016), (Myskiv L., 2014), (Tchaikovsky M., 2015), so the implementation of inclusive education must meet specific requirements and be able to change, adapting to the special educational needs of people with disabilities.

Pedagogical conditions for the implementation of inclusive education combine conditions related to the systems of general and special education. The conditions of the education system cannot fully meet the needs of a person with a disability, they are often conservative, displacing the subjects of the educational process who have individual educational needs. At the present stage, in Ukraine, inclusive education forms a holistic system, which is characterized by special conditions for the inclusion of people with disabilities in the educational environment.

And domestic scientists (LG Budyak, LM Grechko, AA Kolupaeva) determined the conditions for effective provision of inclusive education for children with special needs:

- early detection of malformations and correctional work from the first months of life;

- correct diagnosis of the child's development and taking into account its capabilities;

- psychological readiness of the child and his parents to learn together with healthy peers;

- development of methods of inclusive education depending on the type of dysontogenesis; 
- close cooperation with parents, providing them with the necessary minimum of special education knowledge, psychotherapy and counseling;

- appropriate training of teachers of secondary schools;

- creation of a special educational environment (necessary equipment, security regime, etc.);

- preparation of children with the normative level of development to interact with peers with psychophysical disorders;

- providing psychological and pedagogical support for inclusive education (Budyak L., 2009; Grechko L., 2008; Kolupaeva A., 2009).

The socio-cultural environment in the educational institution should convey the idea of morality, tolerance, humanity, value approach to the personality of each person and contribute to "overcoming the spiritual crisis of modern civilization by means of education as a socio-cultural institution."

Makarenko AS considered the environment as a team and described its impact on each person: "The team, being a common one, at the same time allows each individual to develop their own characteristics, to preserve their individuality" (Chernukha et al, 2019; Tokaruk et al, 2019; Vasylieva-Khalatnykova et al, 2019).

Mudryk A.V. describes the social environment as "very different not only at each age, but also depending on the specific conditions in which a person grows and develops." He notes that the socio-cultural tasks of the environment: "cognitive, moral and ethical, value and content - specific to each age stage in a particular society at a certain period of its history" (Mudryk A., 2015)

We focus on the main segments of inclusion. An inclusive approach to education shows a shift to a "social" model that states: the cause of disability is not in the disease itself; the cause of disability - in existing barriers and stereotypes in society.

The emergence of ideas of affordable education causes deliberate and objective changes in the links within educational systems, resulting in the birth of a new object of research; theory and practice - inclusive education. Thus, a new social phenomenon of development of the Ukrainian educational system appears.

Under the socio-cultural environment of the educational institution we understand "the space of common life, which provides a choice of values, culture, life meanings, ways of cultural self-realization, disclosure of individual resources, the structure of which is determined by the educational institution."

\section{Results Analysis}

The analysis of the definitions of the socio-cultural environment allowed us to form our own definition of the phenomenon for a person with disabilities: the socio-cultural environment is the environment of people in an educational institution, which includes social groups, information flows, influence of various public organizations, cultural and educational activities. objects that jointly affect the change and formation of internal attitudes and external characteristics of the object and its socialization.

The model of socio-cultural environment of inclusion of a modern educational institution includes external and internal factors that have a direct impact on its components, input flows and output (Figure 1). 


\section{Model of socio-cultural environment of inclusion in a modern educational institution}

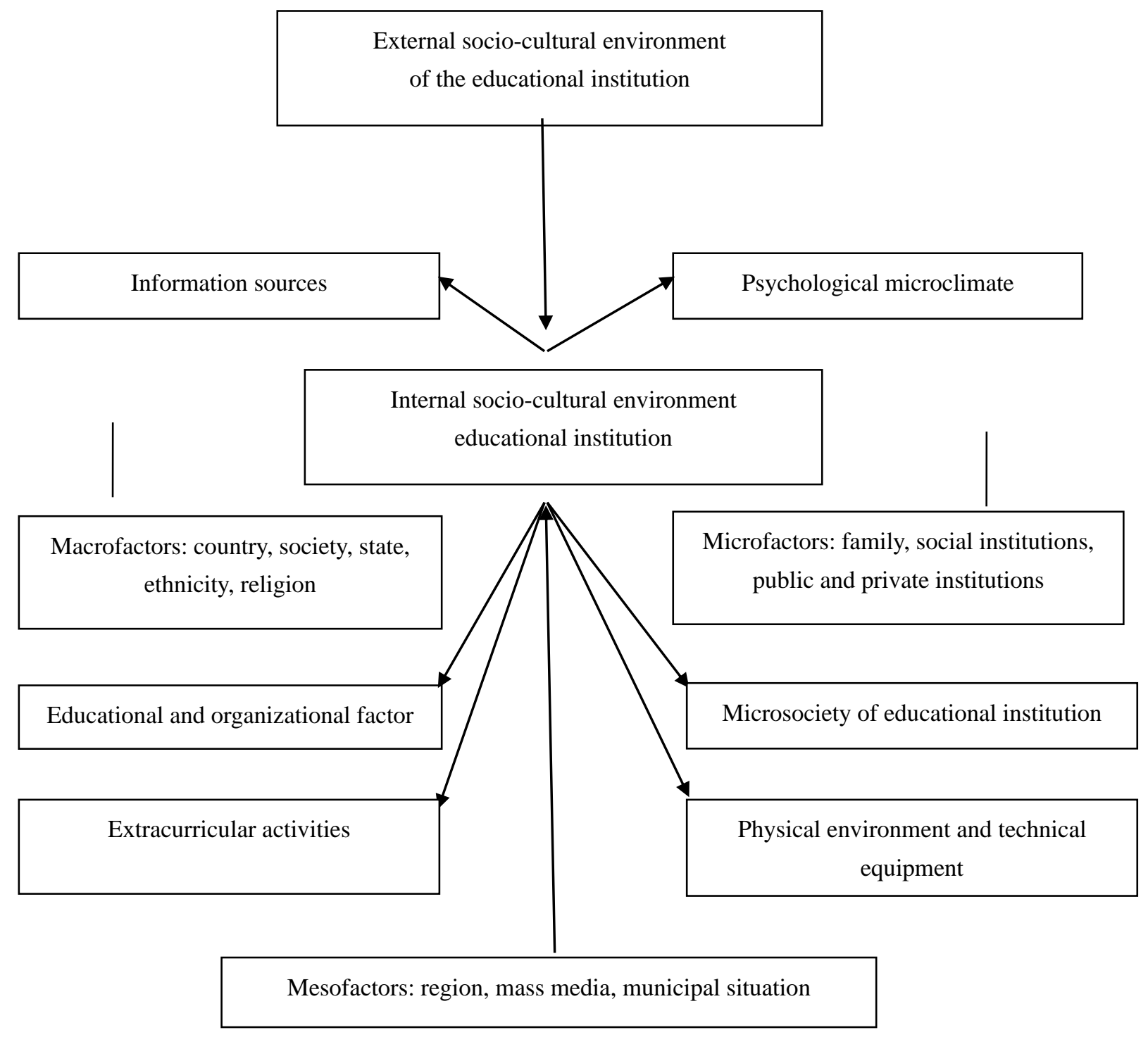

Figure 1. Model of socio-cultural environment of inclusion in a modern educational institution

Source: developed by the authors

Externally, the socio-cultural environment of the educational institution is influenced by a number of factors, which can be divided into the following groups: the macro-factors in this case will include the country, society, state, ethnic group, religion; to mesofactors - regional location, mass media, municipal position; to microfactors - family structure, public, private and religious organizations and foundations (according to Mudryk AV) [9, P. 124].

All these factors create the cultural and social environment of man and affect the activities of educational institutions and the education system as a whole. Depending on the location, the general education system, the traditions of society, culture and religion, the model of the socio-cultural environment of the educational institution may differ significantly.

Consider the practical implementation of the model of socio-cultural environment for a person with disabilities in an educational institution.

The study involved 58 students of Kyiv National Taras Shevchenko University, specialty "Social Pedagogy" aged 17 to 23 years (including 8 students with disabilities) and 18 teachers and staff. Further, all studies were conducted on the same contingent of students, changing only the sample size of the general population. 
Respondents were selected using the "snowball" method. Respondents were selected randomly, using the database of telephone numbers of students of the Taras Shevchenko National University of Kyiv. To recruit respondents, staff approached the deans of faculties working with both students and faculty. Each person invited to participate in the survey was asked to provide contacts of a person who met the characteristics of the target groups of the study. The inclusion criteria for students were studying at the Taras Shevchenko National University of Kyiv and confirmation by the respondents of the fact of active participation in the student life of the university. The criteria for the inclusion of teachers were professional activities with the selected contingent of students and teachers' work at the request of students during non-working hours.

The purpose of the survey was to identify students' attitudes towards people with disabilities.

Research questions:

o Are you ready, as a student / employee of an educational institution, to help a person with a disability in the educational process, as well as when moving around the building, classrooms?

o Are employees of educational institutions ready to provide support to people with disabilities?

o How do you feel as a student / employee of an educational institution to the needs of a person with a disability (attitude within the micro-society)?

o How is your attitude $\$$ Participation of people with disabilities in extracurricular activities?

o Are technical means of rehabilitation for people with disabilities implemented (technical factor)?

o Are the conditions of ergonomic environment and comfortable environment for the movement of people with disabilities (physical factor) implemented? (table 1)

Hypothesis of our survey.

H0: The socio-cultural environment of inclusion of an educational institution is ready to accept a person with a disability.

H1: The socio-cultural environment of inclusion of an educational institution is not ready to accept a person with a disability.

Table 1. Assessment of the conditions of the socio-cultural environment in the educational institution

CRITERIA

Attitudes of students to the inclusion of people with disabilities in the educational system

Readiness of students to provide help and support during the educational process to a person with a disability (psychological factor)

Attitudes of teachers and staff of educational institutions to the needs of people with disabilities (attitudes within the micro-society)

Development of ergonomic environment and comfortable environment for movement (physical factor)

Use of technical means of rehabilitation (technical factor)

Attitude of employees (attitude in the middle of the micro-society)

Participation in extracurricular activities

\section{POINTS}

$66 \%$ of respondents were positive

$43 \%$ of students are ready to provide the necessary assistance

$68 \%$ of teachers and employees of educational institutions have a neutral perception of the needs of a person with a disability

$64 \%$ of respondents noted their absence

$48 \%$ of respondents did not use special technical means in training

$49 \%$ of employees are loyal and positive

$58 \%$ of respondents have a positive attitude to the participation of people with disabilities

Source: developed by the authors

More than half of the students were positive about the development of inclusive education and the admission of students with disabilities to their group, which is a favorable factor in the development of the social environment (Table 1). Students are ready to help a person with a disability in the educational process, as well as when moving around the building, classrooms; $43 \%$ of respondents responded positively. Are employees of educational institutions 
ready to provide support to a person with a disability - students assessed the level of their loyalty in $49 \%$ of cases. According to the results of the study, teachers and staff of educational institutions are not yet ready to teach a person with a disability. Methodological unpreparedness creates barriers to their learning. Another obstacle was the insufficient technical equipment of the educational process with special means of rehabilitation. This affects the adaptation of people with disabilities to the educational and socio-cultural environment, as well as the introduction of inclusive education.

For assessing the significance of differences between the two samples' percentages in which the effect of interest is registered we used Fisher's test.

Table 2. Fisher's test's table

\begin{tabular}{cccc}
\hline Groups & $\begin{array}{c}\text { Is an effect } \\
\text { Quantity }\end{array}$ & $\begin{array}{c}\text { Is no effect } \\
\text { Quantity }\end{array}$ & SUM \\
\hline S & $58(55.8 \%)$ & $46(44.2 \%)$ & $104(100 \%)$ \\
$\mathbf{T}$ & $8(30.8 \%)$ & $18(69.2 \%)$ & $26(100 \%)$ \\
\hline
\end{tabular}

Source: Created by the authors

Axis of significance

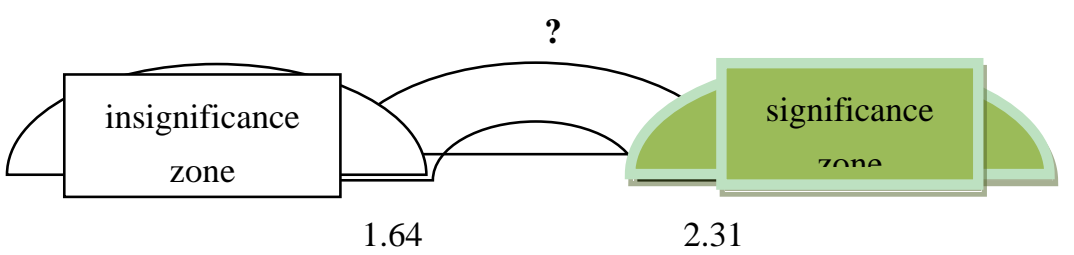

Answer $\varphi^{*}{ }_{\text {эмІ }}=\mathbf{2 . 3 2 6}$

Figure. 2. Axis of significance

Source: Created by the authors

The obtained empirical value of $\varphi *$ is in the zone of uncertainty. So we can reject HO

The obtained results represented that the socio-cultural environment of inclusion of an educational institution is not ready to accept a person with a disability, and hence the need for proper development of the socio-cultural environment of inclusion in a modern educational institution.

The socio-cultural environment of inclusion in a modern educational institution is the source and the condition for establishing a complex system of connections that gradually form social habits of behavior for people with disabilities. The socio-cultural environment of inclusion in the modern educational institution acts in relation to the anomalous subject as an "ideal" form, which not only determines, but as if leads to its development.

\section{Results and Discussions}

People with disabilities are characterized by impulsive behavior, which is manifested in a strong emotional response to external stimuli. In them, emotions provide a direct connection with any environment, including socio-cultural and a direct reaction to it. L. Vygotsky pointed out that in primitive mental life, will and affect are identical. Each affect is at the same time a tendency, and each tendency acquires the trait of affect. In children with moderate and severe mental retardation, emotional experiences are characterized by insufficient differentiation. Any object that satisfies one or another of their needs causes them positive experiences, and one that prevents them - determines the negative (Vygotsky L., 2003).

In the context of inclusion, inclusive education means the complete adaptation of the educational process of each person, taking into account the specific differences of each individual. The basic basis is the adaptation of the educational environment to each person, not a person to the educational environment. The result of this kind of adaptation of society should provide for its socialization not only in the educational process, but how comfortable all participants in the educational process feel in this team.

Scientist Zubareva T. identified the main features of an inclusive environment:

1) cultivation of a system of values to the education, upbringing and personal development of children with psychophysical disorders, the availability of resources for their lives (regulatory, program, information, material and 
technical, etc.), aimed at realizing their individual abilities;

2) definition and implementation of the philosophy of inclusion, the role of the educational institution in the field of important functions of inclusive activities, general approaches and principles of life of pupils with disabilities to implement the tasks of inclusive education, as well as the optimal structure of the educational process;

3) meeting the educational needs of children with mental and physical disabilities and taking into account the interests of their healthy peers;

barrier-free educational process taking into account the special needs of persons in need of correction of psychophysical development;

5) creation of individual-oriented programs taking into account changes in the capabilities of each child in mastering the general level of education;

6) collective formation of an inclusive environment (educators, psychologists, speech pathologists, social educators, exercise instructors, medical staff, etc.);

7) the system of psychological-medical-pedagogical consultations (PMPC), which is created on the basis of educational institution in the presence of relevant specialists and plays a systemic role in supporting and building the educational route of a child with psychophysical disorders, as well as accurate definition of habilitation effects on her (Zubareva T., 2009).

The environment of inclusion is associated with the definition of new knowledge about the common education of man in the educational space of the general type, regardless of their age, level of psychophysical development, socio-economic status. Substantiation of regularities of pedagogy of inclusive education, training and education are called knowledge based on the ideas of inclusion, the principles of humanistic pedagogy, the new educational paradigm. They are designed to provide the theoretical foundations of pedagogical processes in terms of inclusion, to justify the use of adequate methods, forms of joint learning of people with different levels of psychophysical development in terms of general education.

Socio-cultural environment of inclusion in a modern educational institution contributes to the successful process of socialization of people with disabilities, through the creation of imaginary situations, as in real life, where their age and socio-pedagogical characteristics, as well as specific educational environment and social situations influence the choice of goals, objectives. content and means of socio-pedagogical activities. It should be borne in mind that it is the qualified representative of the socio-cultural environment of inclusion who will be able to provide the necessary help, support or support.

For the development of people with disabilities of any skills and habits, for the formation of the necessary knowledge and ideas about the social environment, about behavioral skills, about work, etc. it is necessary to use directly practical supports in correctional and educational work, which should be closely connected with the word. This pattern requires, in addition to explanation, demonstration of certain behaviors, activities, which is not possible without the use of socio-cultural environment of inclusion. Making full use of the socio-cultural environment of inclusion in a modern educational institution helps the formation of new nerve connections in the cerebral cortex of people with disabilities, which has a positive effect on the development of their personality as a whole.

Ensuring the full development of the child implies the unity of the subject-development environment and meaningful communication between adults and children. That is, the environment leads to real changes in a person, promotes his personal development. That is why it is very important manage the process of interaction with the environment, making optimal use of its potential, which is relevant in the process of creating and operating an inclusive environment that will contribute effective inclusion of pupils in need of correction of psychophysical development, realization of their potential abilities. into society.

However, it should be remembered that a child with mental and physical disabilities can not suddenly turn on in the educational environment, as inclusive education is focused on joint activities of parents, educators, psychologists, etc. In addition, an inclusive environment should not be "imposed" educational institution by someone's decision, because it requires a comprehensive readiness of material and technical conditions, human and professional relationships.

The main task of the socio-cultural environment of inclusion in a modern educational institution is to overcome deviations in the development of a pupil with special needs and prevent unwanted negative trends.

The guiding principle of the socio-cultural environment of inclusion in a modern educational institution is its readiness to adapt to the individual needs of different categories of children through structural, functional, 
substantive and technological modernization of the educational system, individual approach, humane relations with each child, play activities.

In our opinion, the implementation of the developed model "Model of socio-cultural environment of inclusion in a modern educational institution" will be an important factor in the development of persons in need of correction of psychophysical development. In particular, the basis for creating a socio-cultural environment of inclusion in a modern educational institution in accordance with the proposed model may be the effective cooperation of several educational institutions.

Such a model will allow to apply in practice a systematic approach to the full inclusion of persons with disabilities society.

In the study, the socio-cultural environment of inclusion of a modern educational institution is considered as a living space that provides an increase in self-esteem and self-confidence of people in need of correction of psychophysical development.

Creating a socio-cultural environment of inclusion in a modern educational institution is a flexible, individualized system that provides not only adaptation of the physical environment, but also teacher training, changing the system of providing students with the opportunity to study according to individual curriculum, providing medical, social, psychological and scientific support. creation of educational programs, educational and methodical support, etc.

\section{Conclusions}

The above helps us to present the findings of the study by revealing the content of the socio-cultural environment of inclusion in a modern educational institution. The socio-cultural environment of inclusion in a modern educational institution should become an intermediate link in creating opportunities in society for the full realization of a person with a disability and its interaction with the environment, as a result of which a person acquires realization and the environment creates the necessary conditions. Thus, the existing segregation in modern educational institutions disappears - the phenomenon of social differences between people with different individual abilities, which must be overcome under a new social paradigm.

People with disabilities, being in the socio-cultural environment of inclusion in a modern educational institution, feel the influence of a number of traumatic factors related to certain factors, such as: the influence and attitude of the "healthy" part of the student body; emergence of a new type of activity (educational) and relevant requirements and needs. If young people who became disabled at a certain age as a result of an accident (illness) show a high level of psychological adaptation, then people who are disabled from childhood have limited experience of positive communication with the social environment, experience psychological trauma to a greater extent.

Involvement of people, in particular students, with disabilities in the sociocultural environment of inclusion at the initial stages of society was spontaneous, informal. The main stages in the evolution of social attitudes towards stydents with disabilities are: the first stage - from indifference and elimination to social neglect of children with developmental disabilities; the second stage - from social neglect to awareness of the possibility of social integration and adaptation of children with developmental disabilities through education; the third stage - from social adaptation through education, differentiation and segregation to social integration of children with developmental disabilities; the fourth stage - from equal rights to equal opportunities.

In the socio-cultural environment of inclusion of the educational institution has certain features that are reflected in its structure. Based on the above socio-cultural environment of inclusion of a modern educational institution is divided into three main groups: the micro-society of the educational institution, consisting of a group of people and connections between them; exchange of information during the learning process; the state of the physical environment of the educational institution and the level of technical equipment; general direction of human training and educational schedule of the institution; psychological settings of the subjects of the educational process; educational process carried out in the form of organization of cultural and extracurricular activities. Here is a more detailed description of these components of the environment of the educational organization.

Education in the socio-cultural environment of inclusion of the educational institution requires the creation of a favorable social situation for the development of students with mental and physical disabilities and ensuring them equal rights in receiving educational services. Structural and semantic features of inclusive education are: the use of adequate and specific forms of educational integration; ensuring the common environment and actions, strengthening the differentiation and individualization of the content of education; direction of education on the formation of social 
and domestic competence of students and harmonization of interpersonal relations in the socio-cultural environment of inclusion of the educational institution.

Information flows, which during the study in the educational institution, include the exchange of educational information between the subjects of the educational process, answers during classes, work in the library, on the global Internet and internal network of the educational institution, communication with peers, media appeal, participation in clubs, sections, should be adapted to the needs of a person with a disability.

The physical environment of the educational institution should be ergonomic and promote the mobility of people with disabilities. This requires the use of lifts, ramps, equipping the training space with elevators, special bathrooms, wide corridors and doorways.

The micro-society of an educational institution must be ready to accept a person with a disability. The socio-psychological climate within the team, which is part of the educational space of the educational institution, depends on the general culture, educational policy, the impact of information flows and internal socio-psychological attitudes of each member of the community. It can be influenced by extracurricular activities - joint holidays, excursions conducted by the educational institution, in order to implement inclusive education and accept people with disabilities.

The model of socio-cultural environment of a modern educational institution for a person with a disability is represented. The given model of the socio-cultural environment of an educational institution for a person with a disability and a practical assessment of its conditions can be applied to any institution of inclusive orientation.

The model reflects the conditions of effectiveness of educational integration in general, is based on system-integrated and personality-oriented approaches, reflects the structural, functional and social orientation of the educational process, reflects the organization of learning based on cognitive capabilities, environment and prospects of integrated students objective relations between people, reproduces the modern vision of everyday life, systematic work on the amplification of social experience of students, preparation for an independent, independent lifestyle.

However, the study does not exhaust the completeness of the problem of using the opportunities of the socio-cultural environment of inclusion in a modern educational institution. Further research requires such important aspects of the problem as the content of training in an inclusion environment.

\section{References}

Badjanova, J., Ilisko, Dz., \& Petrova, M. (2018). Definition and Dynamics of Gender-Specific Behaviours of Latvian Males and Females. Rural Environment. Education. Personality (REEP). (2018). Proceedings of the International Scientific Conference, Volume 11, 11 th - 12 th May 2018. Jelgava: Latvia University of Life Sciences and Technologies. Faculty of Engineering. Institute of Education and Home Economics. ISSN 2255-8071, Jelgava, LATVIA, 11.-12.05.2018, 53-58. https://doi.org/10.22616/REEP.2018.005

Badjanova J., Iliško Dz., Ignatjeva Sv., Petrova M., \& Gorbunovs A. (2020). Evaluation and analysis of personality traits of Latvian and Bulgarian Inhabitants. Periodicals of Engineering and Natural Sciences, Vol. 8, No. 3, July 2020, 1398-1409. http://dx.doi.org/10.21533/pen.v8i3.1516

Baida, L. Yu. (2013). Training module "Interdepartmental approach in the implementation of inclusive education" [in Ukranian]. Canadian-Ukrainian project "Inclusion education for children with special needs in Ukraine ". K., 2013, $47 \mathrm{c}$.

Budyak, L. V. (2009). Fundamentals of inclusive education: a textbook [in Ukranian]. Cherkasy: Type. 2009, 90 p.

Chernukha, N. M., Tokaruk, L. S., \& Vasylieva-Khalatnykova M. O. (2019). Inclusive education: international experience and Ukrainian realities [in English]. Innovative pedagogy, Issue 11, Vol. 3, 2019, 153 - 157.

Christine Ann Walsh, Myra Baynton (2012). Distance Education in Social Work: An Evaluation of an Undergraduate Course on Family Violence [in English]. International Journal of Higher Education, Vol. 1, No. 1, May, 2012, 148-159. https://doi.org/10.5430/ijhe.v1n1p148

Diachok, N., Chernukha, N., Tokaruk, L., Udovenko, I., \& Petrova, M. (2020). Practical-oriented concept as a principle of professional education of the future professionals. International Journal of Higher Education, Vol. 9, No. 4, August 2020, 272-282. https://doi.org/10.5430/ijhe.v9n4p272

Dyachenko, Yu., Nenkov, N., Petrova, M., Skarga-Bandurova, I., \& Soloviov, O. (2018). Approaches to Cognitive Architecture of Autonomous Intelligent Agent. Biologically Inspired Cognitive Architectures, Elsevier, Volume 26, 130-135. https://doi.org/10.1016/j.bica.2018.10.004 
Duginets, G., \& Petrova, M. (2020). The essence of hybrid wars in the XXI century.Professional competencies and educational innovations in the knowledge economy: collectivemonograph / Ed: Lyubomira Popova, Mariana Petrova. Veliko Tarnovo, Bulgaria: Publishing House ACCESS PRESS, 2020. -552 p. ISBN 978-619-91511-0-5, 174-189. http://access-bg.org/ebooks

Grechko, L. M. (2008). Psychological support of children of primary school age with defects of psychophysical development in the conditions of integrated training [in Ukranian]. Candidate's thesis (Special psychology). Kyiv, 2008. 180 pp.

Inclusive education: theoretical and methodological, organizational principles of implementation: teaching method. Way [in Ukranian]. V. I. Schneider; Khmelnytsky. reg. int postgraduate. ped. Education, Dept. pedagogy and psychology, Khmelnytsky: OIPPO, 2010, 176 p.

Inclusive education: theory and practice: teaching method. Way [in Ukranian]. S.P Mironov and others; for general ed. SP Mironova; Kamyanets-Podil. nat. Univ. Ivana Ogienko, Kamyanets-Podilsky, 2012, 191 p.

Inclusive training: organizational, content and methodological support: teaching method [in Ukranian]. Mironova SP and others; for general ed. Mironova SP; Kamyanets-Podil. nat. Univ. Ivana Ogienko, Kamyanets-Podilsky, Kyiv, PNU named after I. Ogienko, 2015, 235 p.

Ivanchuk, S., Voznik, A., Dronova, O., Girenko, N., \& Arsova, D. (2020). Preparation of future preschool education specialists for the use of modern educational technologies. International Journal of Higher Education, 9(5), 28-35. https://doi.org/10.5430/ijhe.v9n5P28

Jarmusevica, V., Ilisko, D., Badjanova, J., Jukss, V., \& Petrova, M. (2019). SMART governance of implementing the strategy of corporate societal responsibility for a sustainable regional development. International Multidisciplinary Scientific GeoConference Surveying Geology and Mining Ecology Management, SGEM 19(5.3), 2019, 645-652. https://doi.org/10.5593/sgem2019/5.3/S21.081

Jarmusevica, V., Ilisko, D., Badjanova, J., Jukss, V., \& Petrova, M. (2019B). Educating citizens for integrating the strategy of corporate social responsibility for sustainable regional development: the case study. Proceedings of EDULEARN19 Conference 1st-3rd July 2019, Palma, Mallorca, Spain, 10449-10454, https://library.iated.org/view/JARMUSEVICA2019EDU, https://doi.org/10.21125/edulearn.2019.2633

Kolupaeva, A. A. (2009). Inclusive education: realities and prospects: Monograph. [in Ukranian]. Kyiv: Summit Book, 2009, 272 p.

Malchyk, M. V. (2015). Competence-oriented economic education: tasks for inclusive education: teaching method [in Ukranian]. Kyiv: University "Ukraine", 2015, 320 p.

Mironova, S. P. (2016). Pedagogy of inclusive education: teaching method [in Ukranian]. Kamyanets-Podilsky: Kamyanets-Podilsky. nat. Univ. Ivan Ogienko, 2016, 163 p.

Mudri, A.V. (2016). Social pedagogy [in Russian]. Moscow, 2016, 342 p.

Mushkudiani, Z., Gechbaia, B., Gigauri, I., \& Gulua, E. (2020). Global, economic and technological trends in human resource management development. Access to science, business, innovation in digital economy, ACCESS Press, 1(1), 53-60. https://doi.org/10.46656/access.2020.1.1(4)

Myskiv, L. I. (2016). Legal problems of inclusive education in Ukraine [in Ukranian]. Kharkiv: NikaNova, 2014, $454 \mathrm{p}$.

Nikolova, M. (2015). Active learning and developing skills and competencies for use of electronic services. Innovations in technology and education: Sat. Art. participants of the VIII International Scientific and Practical Conference "Innovations in Technology and Education", March 5-6, 2015: at 5 tom/ Branch of KuzSTU in Belovo. - Belovo: Publishing house of the KuzGTU branch in Belovo, Russia; 2015. - Part 2. 329 p. $132-137$.

Nikolova, M. (2014). Concept for active learning with electronic educational resources. Technical of university of Varna, Computer science and technologies, Year XII, Number 2/2014, (59-64), ISSN 1312-3335.

Petrova M., Buzko I, \& Dyachenko Yu. (2018). Cognitive, Intelligence Technologies and Economical Foundations of Teaching of International Economical Relations and Tourism. 17th International Scientific Conference ERDev, 23.-25.05.2018. Jelgava, latvia, 1102-1106. https://doi.org/10.22616/ERDev2018.17.N170

Shaparenko, G. V. (2013). Introduction to inclusive education: textbook. [in Ukranian]. Kyiv. Univ. B. Hrinchenko, 2013, 39 p. 
Shevtsiv, Z. M. (2016). Osnovy inklyuzivnoi pedagogiki: pidruchnyk [in Ukranian]. Kyiv: Center for Education. lit., 2016, $247 \mathrm{p}$.

Shved, M. Fundamentals of inclusive education: textbook [in Ukranian]. Lviv: Ukr. Catholic. University, 2015, 358 p.

Tchaikovsky, M. E. (2015). Socio-pedagogical work with youth with special needs in an inclusive educational space: monograph [in Ukranian]. Kyiv: University "Ukraine", 2015, 435 p.

Universal design education (2015). a guide. for teachers [in Ukranian]. Step by Step Foundation, Inclusion Project. education: step by step "; subsection. ed., order. Sofiy NZ - Kyiv: Pleiades, 2015, 76 p.

Vasilieva-Khalatnikova, M. O. (2019). Inclusion in out-of-school educational space for a child with a disability [in Ukranian]. Higher education in Ukraine, 2019. Kyiv, 2019, 84-93.

Vygotsky, L. S. (2003). Principles of education of physically defective children [in Russian]. Fundamentals of defectology. Publishing house "Lan", 2003, 96.

Zagorodnya, A., Chernukha N., \& Petrova, M. (2020). Contemporary trends of professional training specialists in the economic field at higher education institutions of Poland and Ukraine. Strategies for Policy in Science and Education, ISSN 1314-8575 (Online), ISSN 1310-0270 (Print), Volume: 28, Issue: 3, 249-260.

Zubareva, T. G. (2009). Competence-oriented professional development of specialists in creating an inclusive educational environment [in Russian]. Candidate's thesis (Theory and Methods of Vocational Training). Kursk, 2009, 208 pp.

\section{Copyrights}

Copyright for this article is retained by the author(s), with first publication rights granted to the journal.

This is an open-access article distributed under the terms and conditions of the Creative Commons Attribution license (http://creativecommons.org/licenses/by/4.0/). 